\title{
KEPASTIAN HUKUM DALAM PENYELESAIAN KASUS PIDANA MELALUI HUKUM ADAT DITINJAU DARI SISTEM HUKUM NASIONAL
}

Basrawi

Universitas Sembilan Belas November Kolaka

JL. Pemuda No.339, Kolaka 93517, Sulawesi Tenggara, Indonesia

E-mail: basrawisakieb@gmail.com

\begin{abstract}
Abstrak
Hukum adat merupakan hukum tidak tertulis yang secara konstitusi diakui oleh Negara berdasarkan Pasal 18B Ayat (2) Undang - Undang Dasar Negara Republik Indonesia TAhun 1945. Hukum adat mempunyai arti yang sama yaitu sebagai rangkaian norma yang hidup di dalam mayarakat dan mengatur tingkah laku yang bertujuan untuk terciptanya suatu ketertiban dalam masyarakat. Dalam berbagai persoalan yang diselesaikan dengan melalui lembaga Adat adalah bentuk kepastian hukum, sama halnya dengan putusan yang dilahirkan melalui sistem peradilan hukum positif di Indonesia. Hal yang menjadi perbedaan adalah hukum adat yang berlaku di Indonesia tidak tertulis dan tidak dibuat oleh lembaga legislatif. Apa yang terjadi saat ini di tengah - tengah para pencari keadilan, menganggap kepastian hukum hanya ada pada sistem peradilan positif di Indonesia, sehingga muncul suatu permasalahan bagaimana kepastian hukum dalam penyelesaian pidana melalui hukum adat ditinjau dari sistem hukum nasional. Tujuan penelitian ini untuk mengetahui bagaimana kepastian hukum dalam penyelesaiaan kasus pidana melalui hukum adat ditinjau dari sistem hukum nasional. Penyelesaian hukum adat merupakan produk kepastian hukum dalam sistem hukum nasional dan sangat penting untuk mendasari pembangunan hukum nasional. Penyelesaian hukum adat juga mendorong transformasi pemikiran masyarakat untuk memahami nilai-nilai kearifan lokal, norma-norma yang hidup di dalam masyarakat sebagai bagian dari perangkat hukum Negara yang kedudukannya dilegitimasi secara konstitusi. Sehingga apa yang menjadi kesimpulan dalam penyelesaian melalui hukum adat merupakan suatu kepastian hukum sebagai dasar legitimasi dari sistem peradilan hukum nasional yang bertujuan menciptakan ketertiban dan mengembalikan keseimbangan yang hilang di tengah-tengah masyarakat.

Kata Kunci : Kepastian Hukum, Adat, Sistem Hukum Nasional
\end{abstract}




\section{Abstract}

Customary law is an unwritten law that is constitutionally recognized by the State based on the constitution of article 18 B paragraph (2). Customary law has the same meaning, namely as a series of norms that live within the community and regulate behavior that aims to create order in society. In various problems resolved through customary institutions is a form of legal certainty, as well as decisions made through the positive legal justice sistem in Indonesia. The difference is that customary law in force in Indonesia is not written and is not made by the legislature. What is happening now in the midst of justice seekers, considers legal certainty only in the positive justice sistem in Indonesia, so that a problem arises how legal certainty in criminal settlement through customary law is viewed from the national legal sistem. The purpose of this study is to find out how legal certainty in resolving criminal cases through customary law is viewed from the national legal sistem. It can be concluded that the completion of customary law is a product of legal certainty in the national legal sistem and is very important to underpin the development of national law. Completion of customary law also encourages the transformation of people's thinking to understand the values of local wisdom, norms that live within the community as part of a set of state laws whose position is constitutionally legitimized. So that what constitutes conclusions in resolving through customary law is a legal certainty as the basis of legitimacy of the national legal justice sistem which aims to create order and restore the lost balance in the midst of society.

Keywords: Certainty of Law, Customs, National Legal Sistem

\section{A. Pendahuluan}

Istilah hukum adat dikemukakan pertama kali oleh Snouck Hurgrounje, sastrawan timur dari belanda (1894). Sebelum istilah hukum adat berkembang, dikenal dengan adat Recht. ${ }^{1}$ Hukum di Indonesia dengan segala keterbatasannya telah terbangun menjadi suatu sistem. Norma Hukum Indonesia telah teruji oleh waktu lebih dari seabad, melewati berbagai dinamika masyarakat dan sampai saat ini masih berlaku.Sejak pendidikan hukum dilakukan secara formal di Indonesia, sistem hukum di Indonesia menjadi sebuah kajian. Sistem hukum ini terdiri atas komponen jiwa bangsa, komponen

${ }^{1}$ C. Dewi Wulansari, 2012, Hukum Adat Indonesia: Suatu Pengantar, Refika Aditama, Bandung, hlm. 2. 
structural, komponen substansial, dan komponen budaya hukum. ${ }^{2}$ Negara Indonesia adalah negara yang majemuk, keragaman suku dan agama menjadikan banyak perbedaan dalam kebiasaan-kebiasaan cara hidup, hingga cara meneyelesaiakan masalah-masalah yang terjadi ditingkatan masyarakatnya. Tentunya dalam segala perbedaan itu, Negara mengakomodir dengan memproklamirkan pancasila sebagai alat pemersatu bangsa dengan ikatan Bhineka tunggal Ika, berbeda-beda tapi tetap satu.

Sesuai dengan Pasal 1 ayat (3) UUD 1945, negara Indonesia adalah negara hukum. Konsekuensi dari negara hukum ini adalah adanya suatu kepastian hukum. Kepastian hukum mengenai pengakuan hukum adat di Indonesia secara jelas telah diamanatkan dalam Pasal 18B ayat (2) UUD 1945 yang berbunyi "Negara mengakui dan menghormati kesatuan masyarakat hukum adat sepanjang masih hidup dan sesuai dengan perkembangan masyarakat dan prinsip Negara Kesatuan Republik Indonesia yang diatur dalam undang-undang". Sehubungan dengan arah pembangunan hukum nasional sinergitas Undang - Undang Desa dengan pengakuan hukum adat atau hukum tidak tertulis termuat dalam Pasal 103 Kewenangan Desa Adat berdasarkan hak asal usul sebagaimana dimaksud dalam Pasal 19 huruf a Undang - Undang Nomor 6 Tahun 2014 pada meliputi: a. pengaturan dan pelaksanaan pemerintahan berdasarkan susunan asli; $b$. pengaturan dan pengurusan ulayat atau wilayah adat; c. pelestarian nilai sosial budaya Desa Adat; d. penyelesaian sengketa adat berdasarkan hukum adat yang berlaku di Desa Adat dalam wilayah yang selaras dengan prinsip hak asasi manusia dengan mengutamakan penyelesaian secara musyawarah; e. penyelenggaraan sidang perdamaian peradilan Desa Adat sesuai dengan ketentuan peraturan perundang-undangan; $\mathrm{f}$. pemeliharaan ketenteraman dan ketertiban masyarakat Desa Adat berdasarkan hukum adat yang berlaku di Desa Adat; dan g. pengembangan kehidupan hukum adat sesuai dengan kondisi sosial budaya masyarakat Desa Adat.

Hukum Adat adalah aturan tidak tertulis yang hidup di dalam masyarakat adat suatu daerah dan akan tetap hidup selama masyarakatnya masih memenuhi hukum adat yang diwariskan kepada mereka dari para nenek moyang sebelum mereka. Penyelesaiaan dalam kasus pidana melalui hukum adat yang membuahkan hasil merupakan wujud dari kepastian hukum, karena hukum pada fungsinya mengembalikan keseimbangan yang hilang di tengah-

\footnotetext{
${ }^{2}$ Bachsan Mustafa, 2003, Sistem Hukum Indonesia Terpadu, Citra Aditya Bakti, Bandung, hlm. 5-6.
} 
tengah masyarakat dan hasil yang didapatkan dalam proses penyelesaian itu sebagai bentuk wujud dari kepastian hukum itu sendiri. Persoalan yang muncul adalah mengutip dari istilah Ahmad Ali Penyakit Hukum, kekeliruan dalam paradigma hukum masyarakat tentang konsep Negara hukum, "Ketika seseorang belajar ilmu hukum dengan hanya menggunakan pendekatan normatif atau yurisprudensi, berarti seseorang hanya mempelajari ilmu tentang penyakit-penyakit yang harus dihadapi hukum dalam melaksanakan fungsinya secara optimal" yang di dalamnya mencakupi keseluruhan "perbuatan hukum" dan "perbuatan melawan hukum. ${ }^{3}$

Menurut Lawrence M. Friedman, kesulitan jika seseorang hanya menggunakan pendekatan Normatif tentang hukum adalah bahwa ia cenderung menganggap beberapa jenis hukum sebagai mandiri, metasocial life, yang cenderung untuk melupakan fakta struktur-struktur aturan-aturan yang tampak hanya dari satu cara di atas kertas, sementara di dalam kehidupan, kenyataannya benar-benar berbeda. ${ }^{4}$ Kegagalan dalam mengimplementasikan konsep Negara hukum dalam sistem hukum di negara ini sangat terasa. Dapat dibuktikan dengan fakta-fakta yang terjadi over kapasitas dalam lembaga yang disebabkan oleh anggapan masyarakat bahwa, peradilan positif satu-satunya tempat mencari keadilan dan memiliki kepastian hukum yang dilegitimasi oleh sistem peradian. Dengan demikian, implementasi hukum tidak tertulis menjadi tidak jelas eksistensinya, bahkan tidak sedikit masyarakat menempuh jalur adat dikarenakan keraguan dalam kekuatan hukumnya. Padahal secara hukum penyelesaian hukum pidana adat dikuatkan dengan beberapa putusan atau yurisprudensi yang mengakui penyelesaian hukum adat, salah satunya adalah putusan Mahkamah Agung RI Nomor 1644 K/Pid/1988 Tanggal 15 Mei 1991 yang memutuskan tetap menghormati putusan kepala Adat yang memberikan Sanksi Adat terhadap para pelanggar norma hukum adat dan tidak membenarkan badan peradilan umum untuk mengadili kedua kalinya dengan menggunakan pendekatan sistem hukum positif. ${ }^{5}$ Tulisan ini akan membahas mengenai kepastian hukum dalam penyelesaian pidana melalui hukum adat ditinjau dari sistem hukum nasional.

\section{B. Hasil dan Pembahasan}

Jakarta, hlm. 206.

${ }^{3}$ Ahmad Ali, 2012, Teori hukum dan Teori Peradilan, Kencana Prenada Media Group, ${ }^{4}$ Ibid., hlm.208.

${ }^{5}$ C. Dewi Wulansari, op.Cit., hlm. 246. 


\section{Dasar Berlakunya Hukum Adat}

a. Dasar Filosofis

Dasar dari berlakunya hukum adat adalah nilai-nilai dan sikap hukum adat sangat identik, bahkan sudah terkandung dalam butir-butir Pancasila. Sebagai contoh, religio magis gotong royong musyawarah mufakat dan keadilan. Dengan demikian, Pancasila merupakan kristalisasi dari hukum adat. Dasar berlakunya hukum adat ditinjau dari segi filosofi hukum adat yang hidup, tumbuh dan berkembang di Indonesia sesuai dengan perkembangan zaman yang bersifat fleksibel dan sesuai dengan nilai-nilai Pancasila, seperti yang tertuang dalam citacita hukum dan hukum negara pembukaan UUD 1945. UUD 1945 hanya menciptakan pokok-pokok pikiran yang meliputi suasana kebatinan dari UUD 1945. Pokok-pokok pikiran tersebut menjiwai citacita hukum dan hukum negara, baik yang tertulis maupun tidak tertulis. Dalam pembukaan UUD 1945, pokok-pokok pikiran yang menjiwai citacita hukum dasar negara adalah Pancasila. Penegasan pancasila sebagai sumber tertib hukum sangat berarti bagi hukum adat karena hukum adat berakar pada kebudayaan yang nyata dan hidup di kalangan rakyat dan mencerminkan kepribadian masyarakat dan bangsa Indonesia. Dengan demikian, hukum adat secara filosofis merupakan hukum yang berlaku sesuai Pancasila sebagai pandangan hidup atau falsafah hidup bangsa Indonesia. ${ }^{6}$

b. Dasar Sosiologis

Hukum yang berlaku di suatu negara merupakan suatu sistem atau tatanan, artinya merupakan satu kesatuan yang utuh yang terdiri dari bagian-bagian atau usur-unsur yang saling berkaitan satu sama lainnya. Dengan kata lain, sistem hukum adalah suatu kesatuan yang terdiri atas unsur-unsur yang saling berkaitan satu sama lainnya. ${ }^{7}$ sistem hukum berkembang sesuai dengan perkembangan hukum. Selain itu, sistem hukum mempunyai sifat yang berkesinambungan, kontinuitas, dan lengkap. Dalam sistem hukum nasional, wujud/bentuk hukum yang ada dapat dibedakan menjadi hukum tertulis (hukum yang tetuang dalam perundang-undangan). Hukum yang tidak tertulis (hukum adat, hukum kebiasaan). Hukum yang berlaku pada suatu negara dapat dibedakan hlm. 14.

${ }^{6}$ Wignjodipoero, 1998, Pengantar dan Asas - Asas Hukum Adat, Haji Mas Agung, Jakarta,

${ }^{7}$ Mertokusumo, 1986, Hukum Acara Perdata Indonesia, Liberty, Yogyakarta, hlm. 100. 
menjadi hukum yang benar-benar berlaku sebagai the living law (hukum yang hidup) dan yang diberlakukan, tetapi tidak berlaku sebagai the living law. Sebagai contoh, hukum yang berlaku dengan cara diberlakukan adalah hukum tertulis, yaitu dengan cara diundangkan dalam lembaran negara. Hukum tertulis ada yang berlaku sebagai the living law tetapi ada yang berlaku the living law karena tidak ditaati atau dilaksanakan oleh rakyat. ${ }^{8}$

\section{Landasan Yuridis Berlakunya Hukum Pidana Adat}

Sumber hukum pidana Indonesia adalah hukum pidana tertulis dan hukum pidana tidak tertulis. Sumber hukum pidana tertulis adalah KUHP yang berasal dari wetbook van strafrecht voor nederlandsch indie, yang berlaku 1 Januari 1918. Sebelum 1 Januari 1918 di Hindia Belanda berlaku 2 Wvs, ialah Wvs golongan eropa berdasarkan K.B 1866 Nomor 55 dan Wvs untuk orang bumi putera dan yang dipersamakan berdasarkan ordinantie 6 Mei 1872. Dengan demikian, secara formal hukum pidana adat saat itu tidak diberlakukan oleh pemerintah penjajah belanda di hindia belanda, walaupun secara materil tetap berlaku dan tetap diterapkan dalam praktek peradilan. Pemberlakuan hukum pidana adat mendapat landasan hukum dengan dikeluarkannya Undang - Undang Nomor 1 Drt.1951 khususnya Pasal 5 ayat (3) sub b yang pada intinya memuat tiga hal: ${ }^{9}$

a. Tindak pidana adat yang tidak ada bandingannya/padanannya dalam KUHP yang sifatnya tidak berat atau yang dianggap tindak pidana adat yang ringan ancaman pidananya adalah pidana penjara paling lama tiga bulan dan/atau denda lima ratus rupiah (setara dengan kejahatan ringan), minimumnya terdapat dalam pasal 12 KUHP yaitu satu hari untuk penjara dan denda minimum 25 sen sesuai dengan pasal 30 KUHP. Sedangkan untuk tindak pidana adat yang berat ancaman pidananya paling lama 10 tahun, sebagai pengganti dari hukuman adat yang tidak dijalani oleh terhukum.

b. Tindak pidana adat yang ada bandingannya dalam KUHP maka ancaman pidananya sama dengan ancaman pidana yang ada dalam KUHP. Misalnya tindak pidana adat Drati Kerama di Bali yang sebanding dengan zina menurut 284 KUHP.

${ }^{8}$ Dewi Sulastri, 2015, Pengantar Hukum Adat, Pustaka Setia, Bandung, hlm. 72.

${ }^{9}$ Nyoman Serikat Putra Jaya, 2016, Hukum Pidana dan Kriminologi, Pelatihan Hukum Pidana dan Kriminologi III Kerjasama Fakultas Hukum Universitas Lambung Mangkurat dan MAHUPIKI, Banjarmasin, 16-19 Mei, hlm. 3. 
c. Sanksi adat menurut Undang - Undang Darurat No.1 Tahun 1951 di atas dapat dijadikan pidana pokok atau pidana utama oleh hakim dalam memeriksa dan mengadili perbuatan yang menurut hukum yang hidup dianggap sebagai tindak pidana yang tidak ada tandingannya dalam KUHP, sedangkan yang ada bandingannya harus dikenai sanksi sesuai dengan KHUP.

Pengakuan atau pemberian tempat bagi yang hidup atau hukum tidak tertulis sebagai sumber hukum itu, bahkan ditegaskan pula dalam aturan yang bersifat umum, yaitu dalam $:^{10}$

a. Pasal 18 B (2) UUD 1945 (Amandemen Kedua)

Negara mengakui dan menghormati kesatuan-kesatuan masyarakat hukum adat beserta hak-hak tradisionalnya sepanjang masih hidup dan sesuai dengan perkembangan masyarakat dan prinsip negara kesatuan Republik Indonesia yang diatur dalam undang-undang.

b. Undang - Undang Nomor 48 Tahun 2009 tentang Kekuasaan Kehakiman

- $\quad$ Pasal 5 ayat (1) : Hakim dan Hakim Konstitusi wajib menggali, mengikuti dan memahami nilai-nilai hukum dan rasa keadilan yang hidup dalam masyarakat.

- Pasal 50 ayat (1) : Putusan Pengadilan selain harus memuat alasan dan dasar putusan juga memuat pasal tertentu dari peraturan perundang-undangan yang bersangkutan atau sumber hukum tak tertulis yang dijadikan dasar untuk mengadili.

c. Putusan Mahkamah Agung Republik Indonesia

- Putusan Nomor 1644K/Pid/1988 tanggal 15 Mei 1991, antara lain menentukan:

"Seseorang yang telah melakukan perbuatan yang menurut hukum yang hidup (hukum adat) di daerah tersebut adalah merupakan suatu perbuatan yang melanggar hukum adat, yaitu "delict adat". Kepala dan para pemuka adat memberikan reaksi adat (sanksi adat) terhadap si pelaku tersebut. Sanksi adat itu telah dilaksanakan oleh terhukum. Terhadap si terhukum yang sudah dijatuhi "readksi adat" oleh Kepala Adat tersebut, maka ia tidak dapat diajukan lagi (untuk kedua kalinya) sebagai terdakwa dalam persidangan Badan Peradilan Negara (Pengadilan Negeri) dengan dakwaan yang sama,

${ }^{10}$ Ibid., hlm. 4-5. 
melanggar hukum adat dan dijatuhi hukuman penjara menurut KUHP (Pasal 5 ayat (3) b Undang - Undang Nomor 1 Drt 1951). Dalam keadaan yang demikian itu, maka pelimpahan berkas perkara serta tuntutan Kejaksaan di Pengadilan Negeri, harus dinyatakan "tidak dapat diterima" (Niet Onvakelijk Verklaard) (Varia Peradilan VI. No. 72 September 1991)".

- Putusan Nomor 984 K/Pid/1996 tanggal 30 Januari 1996, antara lain berpendirian :

"Perbuatan perselingkuhan suami isteri dengan pihal lain yang selama ini dikenal dengan kualifikasi delik perzinahan ex Pasl 284 KUHP, dan kasus ini ternyata bahwa bilamana si pelaku (dader) telah dijatuhi sanksi adat atau mendapat reaksi adat oleh para pemangku desa adat, dimana hukum adat masih dihormati dan hidup subur didalam masyarakat adat yang bersangkutan, maka penuntutan jaksa terhadap para pelaku (dader) ex Pasa 284 KUHP secara yuridis harus dinyatakan tidak dapat diterima (Varia Peradilan XII, No. 151 April 1988)".Dengan demikian Mahkamah Agung mengakui eksistensi hukum pidana adat serta reaksi adatnya yang masih hidup dalam masyarakat Indonesia.

Hukum adat dalam perkembangannya melalui yurisprudensi dapat ditelusuri dalam beberapa hal yaitu :

1. Prinsip Hukum Adat

Dalam hukum adat menjadikan dasar bahwa hukum adat berasaskan: Rukun, patut, laras, hal ini ditegaskan pada yurisprudensi Mahkamah Agung-RI Nomor 3328/Pdt/1984 tanggal 29 April 1986 dalam putusan MA-RI Nomor 28 tanggal 19 November 1989, berdasarkan sengketa adat yang timbul di Pengadilan Kefamenanu, Nusa Tenggara Timur, dalam penjelasan tersebut muatannya bahwa Mahkamah Agung menegaskan: "dalam menghadapi kasus gugatan perdata yang fundamentum petendi dan petitumnya berdasarkan pada pelanggaran hukum adat dan penegasan sanksi adat bila dalam persidangan penggugat dapat menimbulkan dalil gugatannya, maka hakim harus menerapkan hukum adat mengenai pasal tersebut yang masih berlaku didaerah yang bersangkutan, setelah mendengar tetua adat setempat. Kaidah hukum selanjutnya: "penyelesaian pelanggaran hukum adat, di samping melalui gugatan perdata tersebut di atas, dapat pula ditempuh 
melalui tuntutan pidana Pasal 5 ayat (3) huruf b Undang - Undang Nomor 1 Drt Tahun 1951",.

2. Kedudukan Keluarga Inti Semakin Menguat (Gezin)

Terdapat beberapa golongan masyarakat adat di dalamnya yang sifatnya patrilineal, golongan masayarakat matrilineal dan golongan masyarakat parental (bilateral). Sejauh ini di dalam perkembangannya ternyata semakin kuat dan diakuinya pergeseran sistem kekeluargaan masayarakat adat matrelinial dan masyarakat adat patrinineal ke arah sistem adat parental atau bilateral. Yurisprudensi tanggal 17 Januari 1959 b nomor 320k/Sip/1958 sebagai berikut:

a. Si istri dapat mewarisi harta pencaharian sang suami yang meninggal dunia.

b. Anak yang belum dewasa dipelihara dan berada dalam pengampuan ibu.

c. Karena anak berada dalam pengampuan ibu, maka harta kekayaan anak dikuasai dan di urus oleh ibu.

d. Kedudukan sama laki dan perempuan.

Dalam beberapa Yurisprudensi penting tentang Hukum pidana adat adalah:

1. Perbuatan melawan Hukum. Misalnya PN Luwuk No. 27/Pid/1983, mengadili perkara hubungan kelamin di luar perkawinan, hakim memutus terdakwa melanggar hukum yang di hupo di wilayah banggai, Sulawesi Tengah, berdasarkan unsur pidana dalam Pasal 5 ayat (3) sub b UU Drt 1/ drt/1951, yang unsurnya adalah: Unsur pertama, suatu perbuatan melanggar hukum yang hidup; Unsur kedua, perbuatan pelanggaran tersebut tidak ada bandingannya dalam KUHP; Unsur ketiga, perbuatan pelanggaran tersebut masih tetap berlaku untuk kaula-kaula dan oarng orang yang bersangkutan. Putusan PT Palu No. 6/Pid/1984 tanggal 9 April 1984 menguatkan putusan PN Luwuk, dengan menambahkan bahwa, untuk memenuhi rasa keadilan masyarakat, yang menganggap perbuatan tersebut adalah perbuatan pidana, hakim memutuskan terdakwa telah melakukan kejahatan bersetubuh dengan seorang wanita di luar nikah. Mahkamah Agung, dengan putusan No. 666K/ Pid/ 1984 tanggal 23 Februari 1985, perbuatan yang dilakukan terdakwa dikategorikan sebagai perbuatan zina menurut hukum adat. Mahkamah Agung dalam putusan Nomor 3898K/Pdt/1989, tanggal 19 Nopember 1992, mengenai pelanggaran 
adat serupa di daerah Kafemenanu, mamun diajukan secara perdata dengan gugatan, intinya: Jika dua orang dewasa melakukan hubungan kelamin atas dasar suka sama suka yang mengakibatkan di perempuan hamil, dan si laki-laki tidak bertanggung jawab atas kehamilan tersebut, harus ditetapkan suatu sanksi adat berupa pembayaran belis (biaya atau mas kawin) dari pihak laki-laki kepada pihak perempuan (dikenal dengan nama Pualeu Manleu).

2. Perbuatan melanggar hukum adat Logika Sanggraha di Bali. Dalam perkara Nomor 854K/Pid/1983 tanggal 30 Oktober 1984, Menurut Mahkamah Agung, seorang laki-laki yang tidur bersama dengan seorang perempuan dalam satu kamar dan pada satu tempat tidur, merupakan bukti petunjuk bahwa laki-laki tersebut telah bersetubuh dengan wanita itu. Berdasarkan keterangan saksi korban dan adanya bukti petunjuk dari para saksi-saksi lainnya, terdakwa telah bersetubuh dengan saksi korban sebagaimana dimaksud dalam dakwaan subsider. Mengenai dakwaan primer, Mahkamah Agung berpendirian bahwa dakwaan ini tidak terbukti dengan sah, karena unsur barang dalam pasal 378 KUHP tidak terbukti degan sah dan meyakinkan, dengan demikian maka terdakwa harus dibebaskan datri dakwaaan primer ex pasal 378 KUHP. Berdasarkan pertimbangan di atas Mahkamah Agung dalam diktum putusannya berbunyi: 1 . Membebaskan terdakwa dari dakwaan primer; 2. Menyatakan terdakwa bersalah terhadap dakwaan subsider melakukan tindak pidana adat Logika Sanggraha; 3. Menghukum terdakwa dengan hukuman penjara dua bulan; Hukum adat pidana Logika Sanggraha di Bali Peswara Bali, merupakan suatu perbuatan seorang pria yang memiliki unsur-unsur: - bersetubuh dengan seorang gadis; - Gadis tersebut menjadi hamil karenanya; - Pria tersebut tidak bersedia mengawini gadis tersebut sebagai istrinya yang sah.

3. Putusan Pengadilan Negeri Mataram No. 051/Pid.Rin/1988 tanggal 23 Maret 1988. Pengadilan mempertimbangkannnya telah menyebut pelanggaran terhadap hukum adat delik Nambarayang atau Nagmpesake.

4. MA-RI Nomor $481 \mathrm{~K} / \mathrm{Pid} / 1986$ tanggal 31 Agustus 1989 dari PN Ende Problematika Organ Tubuh Wanita, beberapa kali diterapkan ketentuan pasal 378 KUHP, menempatkan organ tubuh peremuan sebagai barang. Solusinya diterapkan pasal 5 (3) b Undang-undang Drt Nomor 1 Tahun 
1951 LN. Nomor 9 Tahun 1950 tanggal 13 Januari 1951. Dalam kasus serupa di pengadilan Negeri Medan Nomor 571/KS/1980 tanggal 5 Maret 1980 pernah diterapkan ketentuan pasal 378 KUHP dan dikuatkan oleh PT Nomor 144/Pid/1983 tanggal 8 Agustus 1983. Barang ditafsirkan secara luas, sehingga barang termasuk juga jasa. Barang sesuatu yang melekat bersatu pada diri seseorang (kemaluan) juga termasuk pengertian barang, yang dalam bahasa Tapanuli dikenal dengan "Bonda" yang artinya "barang" yang tidak lain adalah "kemaluan". Sehingga bila seorang gadis menyerahkan kehormatannya kepada pria, maka samalah artinya gadis tersebut menyerahkan barang kepada pria tersebut. Dengan penafsiran secara luas tersebut, maka telah terpenuhi unsur barang dalam pasal 378 KUHP. Dalam praktek kemudian banyak diikuti penegak hukum ( jaksa) Untuk menjerat seorang pria yang berhasil menyetubuhi gadis yang akan dikawini, tetapi akhirnya pria ingkar janji, dan gadis menjadi korban yang merana seumur hidup

\section{Kesimpulan}

Negara mengakui terhadap penyelesaian kasus-kasus pidana yang diselesaikan melalui hukum adat, sehinga apa yang diputuskan dalam penyelesaian hukum adat merupakan sebuah kepastian hukum yang harus diakui oleh negara sebagai suatu sistem yang tidak tertulis. Kedudukan hukum adat dalam sistem hukum di negara Repulik Indonesia sama kedudukannya pada umummnya, yang membedakan adalah hukum adat merupakan sistem hukum yang tidak tertulis dan hanya berlaku terhadap orang Indonesia saja. Dengan demikian Mahkamah Agung mengakui dalam beberapa putusan masalah adat yang telah diurai dalam pembahasan di atas sebagai eksistensi hukum pidana adat serta reaksi adatnya yang masih hidup dalam masyarakat Indonesia.

\section{Daftar Pustaka}

\section{Buku:}

Ali, Ahmad, 2012, Teori Hukum dan Teori Peradilan, Kencana Prenada Media Group, Jakarta.

Mertokusumo, 1986, Hukum Acara Perdata Indonesia, Liberty, Yogyakarta.

Mustafa, Bachsan, 2003, Sistem Hukum Indonesia Terpadu, Citra Aditya Bakti, Bandung. 
Sulastri, Dewi, Pengantar Hukum Adat, Pustaka Setia, Bandung.

Wignjodipoero. 1998, Pengantar dan Asas - Asas Hukum Adat, Haji Mas Agung, Jakarta.

Wulansari, Dewi, 2012, Hukum Adat Indonesia Suatu Pengantar, Refika Aditama, Bandung.

\section{Artikel:}

Jaya, Nyoman Serikat Putra, 2016, Hukum Pidana dan Kriminologi, Pelatihan Hukum Pidana dan Kriminologi III kerjasama Fakultas Hukum Universitas Lambung Mangkurat dan MAHUPIKI, Banjarmasin, 16-19 Mei.

\section{Peraturan Perundang - Undangan}

Undang - Undang Dasar Negara Republik Indonesia Tahun 1945.

Undang - Undang Nomor 6 Tahun 2014 tentang Desa. 